conscientious doctor should surely demand an active commitment to protecting tropical forests.

Julian CALdecott

Programme Director for Southeast Asia,

Earthlife Foundation,

London SW1X 8PH

Address for correspondence: 7 Jalan Bukitan, Kuching, Sarawak, Malaysia.

1 Lewis WH, Elvin-Lewis MPF. Medical botany: plants affecting man's health. New York: John Wiley, 1977.

2 Myers N. The primary source: tropical forests and our future. New York: W W Norton, 1984.

3 Myers N. The plant kingdom-a material underpinning of our daily lives-is grossly threatened. Joumal of the Royal Society of Arts 1985;134:38-44.

4 Schultes RE. The Amazon as a source of new economic plants. Economic Botany 1980;33:259-66. 5 Ayensu ES. Medicinal plants of the West Indies. Algonac, Michigan: Reference Publications, 1981 6 Ayensu ES. Medicinal plants of West Africa. Algonac, Michigan: Reference Publications, 1978.

Perry LM. Medicinal plants of East and Southeast Asia. Cambridge, Mass: MIT Press, 1980.

8 Gorinsky C. Plants, primitive people and conservation. In: Sitwell N, ed. Wildlife '76: the world conserv'ution vearbook. London: Danbury Press, 1976:108-13.

9 Hansson A, Veliz G, Naquira C, Amren M, Arroyo M, Aravelo G. Preclinical and clinical studies with latex from Ficus glabrata $\mathrm{Hbk}$, a traditional intestinal anthelminthic in the Amazonian area. F Ethnopharmacol 1986;17:105-38.

10 Janzen DH. Eicology of plants in the tropics. London: Arnuld, 1975.

11 Rosenthal GA, Janzen DH, eds. Herbivores: their interaction with secondary plant metabolites. New York: Academic Press, 1979.

\section{Health and safety in small businesses}

Britain has moved away from direct government enforcement of health and safety legislation towards a system of self regulation by both management and trades unions. Inspectors of the Health and Safety Executive monitor the system and retain powers to bring the laggards into line. The system works well in the large industries, but with some smaller factories there may well be cause for concern. Recently an official on his first visit:

"discovered a boy working in a room measuring $9 \mathrm{ft} 10$ in $\times 9 \mathrm{ft} 2$ in $\times 5 \mathrm{ft} 4 \mathrm{in}$. Near the only door was a heated diesel tank giving off copious fumes. The boy was drilling holes in printed circuit boards. The company had provided him with a plastic tube to breathe through, with one end of the pipe in his mouth and the other hung out of an open window."

This description is taken not from the report of a bewhiskered Victorian inspector but from a report of the Health and Safety Executive for 1984. ${ }^{1}$ The company employed 15 people and was manufacturing electronic equipment for an underwater gas field.

But is this typical of small businesses? We do not know, but the chairman of the Health and Safety Commission's small firms working group, Dr Cedric Thomas, recently told a meeting of employers in Birmingham that the commission was increasingly worried about the safety performance of small firms. "People working in manufacturing firms employing less than 100 people," he said, "run a much higher risk-perhaps $50 \%$ higher-of suffering a serious accident than those who work in larger establishments."' As about half a million people work in firms with between 20 and 50 employees this is an important concern. ${ }^{3}$

The entrepreneur trying to start his own business has a host of government regulations and departments besetting him: value added tax, pay as you earn, statutory sick pay, employment protection, consumer law, the Data Protection Act, fire precautions, and health and safety. Many of them $\vec{z}$ will bring in different inspectors, and it is not surprising that the small businessman can find them confusing ${ }^{45}$ and maybe less than helpful. Against this background the government has published its white paper, Lifting the Burden, which proposed "reducing burdens imposed on businesses by administrative and legislative regulation" while acknowledging that "the line between liberty and licence is fine."

Small businesses cannot possibly have in house expertise $\overrightarrow{\vec{D}}$ in all those specialist responsibilities, yet some are engaged in hazardous processes. One possibility is for individual firms to participate in some kind of shared or group service; but apart $\frac{\bar{\sigma}}{\overline{0}}$ from the difficulties of organising such a scheme, some firms $\stackrel{\Phi}{2}$ may be burdened with unnecessary costs because their needs are not likely to coincide precisely. Yet something is needed $\vec{\partial}$ because workers in those small firms which do create hazards for their workpeople are usually not members of unions and lack the protection afforded by a dialogue of trained management and union representatives.

Over 200 years ago Adam Smith perceived that the interests of society followed naturally from the entrepreneur's concern with his business success: "Generally, indeed [he] neither intends to promote the public interest, nor knows how much he is promoting it ... by directing that industry in such a manner as its product may be of the greatest value he intends only his own gain and he is in this, as in so many other cases, led by an invisible hand to promote an end which was not part of his intention."

Today, the influence of the famous "hidden hand" is reinforced by government regulations, trade union activities, and the mass media. Voluntary constraints-although perhaps springing from self interest, as Smith astutely (if not cynically) observed-have been largely accepted by employers; in many cases these have been incorporated into legislation. The industrial practices of past generations are too often readily condemned by their successors. It is certainly easy to be wise after the event, but it is far more difficult to make wise decisions and develop effective policies that result in problems solved, not merely changed in substance.

Professor of Occupational Health

W R LEE

University of Manchester,

Manchester M13 9PT

Director,

Small Business Development Unit,

Manchester Business School,

Manchester M15 6PB

1 Health and Safety Executive. Manufacturing and service industries 1984 report. London: HMSO, 1985:12.

2 Thomas C. Quoted in: Accident record of small firms causing concerm. Press release from Health and Safety Commission, Regina House, 259/269 Marylebone Road, London NW1 SRR. 16 March 1987.

3 Office of Population Censuses and Surveys. Annual abstracts of statistics. London HMSO: 1986. (No 122: table 6.16)

4 Jefferys M, Wood CH. A Survey of Small Factories. Br I Ind Med 1960;17:10-24

5 Lee WR. A Survey of the Medical Needs of a Group of Small Factories. $\mathrm{Br} \mathcal{F}$ Ind Med 1962;19:186-94.

Minister without Portfolio. Lifting the Burden. London: HMSO, 1985. Cmnd 9571.

7 Health and Safety Commission. Control of substances hazardous to health. Draft regulations and draft approved codes of practice. London: HMSO, 1984. (consultative document.)

8 Smith Adam. An inquiny into the causes of the wealth of nations. Methuen, 1961. (Carman ed.) 